\title{
РІЗНОВИДИ ПСИХОФІЗИЧНОЇ ГОТОВНОСТІ ПОЛІЦЕЙСЬКОГО КРИМІНАЛЬНОӦ ПОЛІЦІЇ В КОНТЕКСТІ НОРМАТИВНО-ПРАВОВОГО ЗАБЕЗПЕЧЕННЯ
}

Дьорова О. М.

\begin{abstract}
Діяльність поліцейських має велике значення для суспільства, оскільки вона спрямована на захист прав і свобод кожної людини. У процесі входження України у світовий освітньо-професійний простір висуваються підвищені вимоги до проблеми забезпечення якісного освітнього рівня фахівців, у тому числі і професійної підготовки висококваліфікованих майбутніх працівників підрозділів Національноі поліції. Для забезпечення високого рівня набуття майбутніми фахівцями необхідних компетентностей важливою складовою частиною $є$ не тільки створення необхідних умов для навчання, але й формування достатньо високого рівня психофізичної готовності поліцейського.
\end{abstract}

Ключові слова: готовність, налаштованість, поліцейський, психологічна готовність, фізична готовність, вогнева готовність, тактико-спеціальна готовність.

Деятельность полицейских имеет большое значение для общества, так как она направлена на защиту прав и свобод каждого человека. В процессе вхождения Украины в мировое образовательно-профессиональное пространство предъявляются повышенные требования к проблеме обеспечения качественного образовательного уровня специалистов, в том числе и профессиональной подготовке высококвалифицированных будущих сотрудников подразделений Национальной полиции. Для обеспечения высокого уровня приобретения будущими специалистами необходимых компетенций важной составляющей является не только создание необходимых условий для обучения, но и формирование достаточно высокого уровня психофизической готовности полицейского.

Целью статьи является установление видов психофизической готовности полицейского криминальной полиции в контексте нормативно-правового обеспечения. Для достижения этой цели выделены разновидности психофизической готовности полицейского криминальной полиции; определено содержание каждой из разновидностей психофизической готовности на основе анализа нормативно-правовых актов, которые регламентируют деятельность полицейского.

Ключевые слова: готовность, настрой, полицейский, психологическая готовность, физическая готовность, огневая готовность, тактико-специальная готовность.

Activity of police officer is of great importance to society, as it is aimed at protecting the rights and freedoms of every person. In the process of Ukraine's entry into the educational and professional world space, increasing demands are placed on the problem of ensuring the quality of educational level of specialists, including the professional training of highly qualified future employees of the National Police. To ensure a high level of acquisition by future specialists of the necessary competencies, an important component is not only the creation of the necessary conditions for training, but also the formation of a sufficiently high level of psychophysical readiness of the police officer.

The purpose of the article is to establish the types of psychophysical readiness of the police officer of the criminal police in the context of regulatory support. To achieve these goals, the types of psychophysical readiness of the police officer of criminal police were identified, the content of each of the varieties of psychophysical readiness was determined on the basis of the analysis of normative legal acts regulating the activity of the police officer.

In the proposed article the author firstly identified and provides his own interpretation of such varieties of psychophysical willingness of the policemen of criminal police as the psychological willingness, physical willingness, fire willingness and tactical special willingness. Emphasizes that each of the varieties is an integral interacting component. In general they compose psychophysical willingness which is the policemen's preference in the criminal police to exercise its powers at a high professional level.

On the basis of the analysis of legal acts regulating the activity of the police officer, the content of the above varieties of psychophysical willingness is disclosed. Special attention during the research was paid to the Criminal Code of Ukraine and the Law of Ukraine On National Policy, which determines the legal basis for the organization and activities of the policeman and the order of service in the National police of Ukraine.

Key words: willingness, preference, policemen, psychological willingness, physical willingness, rifle willingness, tactical special willingness.

Постановка проблеми та іï актуальність. Підготовка молодих спеціалістів для органів та підрозділів Національної поліції України, в тому числі й підрозділів кримінальної поліції, має велике значення. Відповідно, сьогодні для вищої освіти постає головне завдання - створити необхідні умови для набуття майбутніми фахівцями необхідних компетентностей та досягнення певного стану психофізичної готовності до діяльності.

Під час вивчення наукової літератури помічаємо факт недостатнього дослідження проблемних питань психофізичної готовності. Так, попри відсутність чітких та єдиних тверджень щодо його становлення, а також різнобічність наукових думок відносно сутності поняття «психофізична готовність», зовсім не досліджено їі різновиди, в тому числі й різновиди психофізичної готовності поліцейського кримінальної поліції через призму нормативно-правового забезпечення.

Аналіз останніх досліджень i публікацій. Щодо готовності в загальному аспекті, то, досліджуючи іiі характеристики до професійної діяльності, Є.Ф. Зеєр [1] визначає два рівні. На першому рівні готовність розглядається як бажання, прагнення оволодіти якоюсь професією, спеціальністю, на другому - як здатність, підготовленість до професійної діяльності. На другому рівні готовність до професійної діяльності розгляда- 
ється як вже сформованість необхідних для їі успішного здійснення якостей (професійних, особистісних), умінь, навичок, знань [1].

Е.Г. Слободнюк [2] зазначає, що компоненти готовності повинні утворювати і утворюють цілісну систему, оскільки, будучи взяті окремо, вони здатні забезпечити тільки вирішення низки приватних завдань, і тільки їх сукупність дає можливість досягти мети, сформувати нову якість (властивість) особистості - готовність до професійної діяльності [2]. Загалом, підготовка компетентного майбутнього оперативного працівника кримінальної поліції, спроможного до виконання службово-бойових завдань та самовдосконалення, базується на психофізичній готовності. Однак про стан налаштованості та стан готовності не прописано та не згадується в жодному нормативно-правовому акті.

Метою статті $\epsilon$ дослідження різновидів психофізичної готовності поліцейського кримінальної поліції в контексті нормативно-правового забезпечення. Завдання: 1) виокремити різновиди психофізичної готовності поліцейського кримінальної поліції; 2) визначити зміст кожного з різновидів психофізичної готовності на основі аналізу нормативно нормативно-правових актів, які регламентують діяльність поліцейського кримінальної поліції.

У статті вперше досліджено різновиди психофізичної готовності та проаналізовано їхній зміст через призму нормативно нормативно-правових актів, які регламентують діяльність поліцейського кримінальної поліції.

Виклад основного матеріалу. Законодавчим підґрунтям, на який опирається поліцейський у своїй діяльності, є: 1) Закони України: Конституція України [3], Кримінальний кодекс України [4], Кримінальний процесуальний кодекс України [5], «Про Національну поліцію» [6], «Про державну службу» [7], «Про оперативно-розшукову діяльність» [8], «Про організаційно-правові основи боротьби з організованою злочинністю» [9], «Про Дисциплінарний статут органів внутрішніх справ України» [10] та ін.; 2) постанова КМУ «Положення про Національну поліцію» [11]; 3) накази МВС України «Інструкція про порядок проведення атестування поліцейських» від 17.11.2015 № 1465 [12], «Інструкція з організації реагування на заяви та повідомлення про кримінальні, адміністративні правопорушення або події та оперативного інформування в органах (підрозділах) Національної поліції України» від 16.02.2018 № 111 [13], «Положення про організацію службової підготовки працівників Національної поліції України» від 26.01.2016 року № 50 [14], «Про затвердження Порядку організації системи психологічного забезпечення поліцейських, працівників Національної поліції України та курсантів (слухачів) закладів вищої освіти із специфічними умовами нав- чання, які здійснюють підготовку поліцейських» від 06.02.2019 № 88 [15], «Про затвердження Положення з організації перевірки рівня фізичної підготовленості кандидатів до вступу на службу в Національну поліцію України» від 9 лютого 2016 р. № 90 [16] та інші нормативно-правові акти.

Аналізуючи нормативну основу, яка визначає повноваження поліцейського кримінальної поліції, зазначимо, що регламентовані обов'язки передбачають високий рівень психофізичної готовності. Так, п. 1 ст. 2 Закону України «Про Національну поліцію» [6] передбачає основні завдання поліції, серед яких $€$ надання поліцейських послуг у сферах: забезпечення публічної безпеки і порядку; охорони прав і свобод людини, а також інтересів суспільства і держави; протидії злочинності [6]. Виконання завдань такого характеру вимагає від поліцейського вжиття невідкладних заходів, що зазначені в п. 1. ст. 42 ЗУ «Про Національну поліцію» [6], а саме: «Поліція під час виконання повноважень, визначених цим Законом, уповноважена застосовувати такі заходи примусу: 1) фізичний вплив (сила); 2) застосування спеціальних засобів; 3) застосування вогнепальної зброї ...» [6].

На нашу думку, слід виокремити чотири основні види психофізичної готовності: психологічну, фізичну, стрілецьку та тактико-спеціальну (див. рис. 1).

Отже, охарактеризуємо кожний із видів психофізичної готовності через призму нормативно-правових актів. Готовність вважається внутрішнім налаштуванням («настроєм») особи та $\epsilon$ кінцевим результатом психологічної підготовки.

Так, на нашу думку, виходячи з норм зУ «Про національну поліцію» [6], психологічна готовність поліцейського кримінальної поліції виявляється у психічній самоналаштованості особи до:

1) неухильного дотримання положень Конституції України, законів України та інших нормативно-правових актів, що регламентують діяльність поліції, та Присяги поліцейського (п. 1 статті 18 Закону) [6];

2) професійного виконання своїх службових обов'язків відповідно до вимог нормативно-правових актів, посадових (функціональних) обов'язків, наказів керівництва (п. 2 статті 18 Закону) [6];

3) надання невідкладної, зокрема домедичної і медичної допомоги особам, які постраждали внаслідок правопорушень, нещасних випадків, а також особам, які опинилися в безпорадному стані або стані, небезпечному для їхнього життя чи здоров'я; (п. 4 статті 18 Закону) [6];

4) виявлення причин та умов, що сприяють вчиненню кримінальних правопорушень, вжиття в межах своєї компетенції заходів для їх усунення (п. 2 статті 23 Закону) [6];

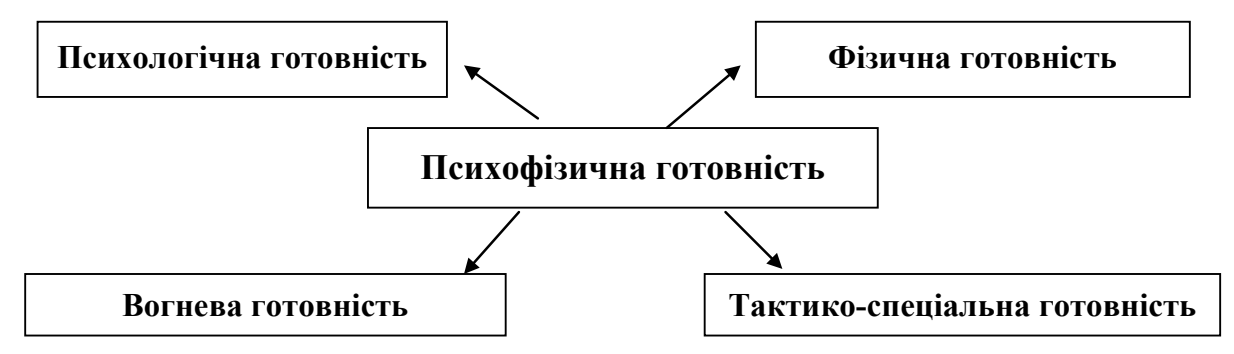

Рис. 1. Види психофізичної готовності 
5) вжиття заходів, спрямованих на усунення загроз життю та здоров'ю фізичних осіб і публічній безпеці, що виникли внаслідок учинення кримінального, адміністративного правопорушення (п. 4 статті 23 Закону) [6];

6) здійснення своєчасного реагування на заяви та повідомлення про кримінальні правопорушення або події (п. 5 статті 23 Закону) [6];

7) розшуку осіб, які переховуються від органів досудового розслідування, слідчого судді, суду, ухиляються від виконання кримінального покарання, пропали безвісти, та інших осіб у випадках, визначених законом (п. 7 статті 23 Закону) [6];

8) вжиття заходів для визначення осіб, які не здатні через стан здоров'я, вік або інші обставини повідомити інформацію про себе; встановлювати особу за невпізнаним трупом (п. 15 статті 23 Закону) [6];

9) здійснення оперативно-розшукової діяльності (п. 26 статті 23 Закону) [6];

10) безпосереднього переслідування осіб, підозрюваних у вчиненні злочину (пп.2 п.1 статті 38 Закону) [6];

11) вжиття заходів щодо припинення злочину, що загрожує життю осіб, які знаходяться в житлі або іншому володінні (пп.3 п.1 статті 38 Закону) [6] тощо.

Відповідно до Кримінального процесуального кодексу України [5] психологічна готовність є налаштованістю до:

12) проведення слідчих (розшукових) дій, а саме:

12.1) допиту (ст. 224 КПК України) [5], допиту свідка, потерпілого під час досудового розслідування в судовому засіданні (ст. 225 КПК України) [5], допиту малолітньої або неповнолітньої особи (ст. 226 КПК України) [5];

12.2) пред'явлення для впізнання (ст. 228- 230 КПК України) [5],

12.3) проникнення до житла чи іншого володіння особи (ст. 233 КПК України) [5];

12.4) обшуку (ст. 234 КПК України); огляду (ст. 237 КПК України) [5], огляду трупа (ст. 238 КПК України) [5];

12.6) слідчого експерименту (ст. 240 КПкУкраїни) [5];

12.7) освідування особи (ст. 241 КПК України) [5];

13) проведення негласних слідчих (розшукових) дій [5]:

13.1) огляду і виїмки кореспонденції (ст. 262 КПК України) [5];

13.2) обстеження публічно недоступних місць, житла чи іншого володіння особи (ст. 267 КПК України) [5];

13.3) спостереження за особою, річчю або місцем та ін. [5];

14) розшуку підозрюваного (ст. 281 КПК України) [5].

Відповідно до ЗУ «Про оперативно-розшукову діяльність» [8] nсихологічна готовність $є$ налаштованістюдо:

15) вжиття необхідних оперативно-розшукових заходів щодо попередження, своєчасного виявлення і припинення злочинів та викриття причин і умов, які сприяють вчиненню злочинів; здійснення профілактики правопорушень (п. 1 ст. 7) [8];

16) виконання письмових доручень слідчого, вказівок прокурора та ін. (п. 2 ст.7) [8];

17) взаємодії між собою та іншими правоохоронними органами, в тому числі відповідними органами іноземних держав та міжнародних антитерористичних організацій, з метою швидкого і повного попередження, виявлення та припинення злочинів (п. 5 ст. 7) [8];
18) прийняття участі у здійсненні заходів щодо фізичного захисту ядерних установок, ядерних матеріалів, радіоактивних відходів, інших джерел іонізуючого випромінювання, а також у проведенні спеціальної перевірки щодо допуску до особливих робіт (п. 7 ст. 7) [8];

19) проведення операцій із захоплення злочинців, припинення злочинів, розвідувально-підривної діяльності спецслужб іноземних держав, організацій та окремих осіб (п. 5 ст. 8) [8];

20) виконання спеціальних завдань із розкриття злочинної діяльності організованих груп чи злочинних організацій (п. 8 ст. 8) [8] тощо.

Психологічну готовність поліцейського можна вважати своєрідним фундаментом його дій під час виконання службових обов'язків. Адже знання своїх психологічних особливостей дозволяє йому керувати власною психікою та ефективно діяти у складних напружених ситуаціях (наприклад, психологічний настрой поліцейського щодо своєчасного використання вогнепальної зброї або застосування тактичних прийомів для затримання злочинця).

Отже, психологічна готовність поліцейського $\epsilon$ різновидом психофізичної готовності, яка виявляється у внутрішньому психологічному налаштуванні чітко та активно виконувати свої професійні функції в будь-яких умовах службової діяльності.

Відповідно до ЗУ «Про національну поліцію» [6] фізична готовність поліцейського кримінальної поліції виявляється у фізичному налаштуванні особи до:

1) вжиття заходів із метою виявлення кримінальних, адміністративних правопорушень; припинення виявлених кримінальних та адміністративних правопорушень (п. 3 статті 18 Закону) [6];

2) вжиття заходів, спрямованих на усунення загроз життю та здоров'ю фізичних осіб і публічній безпеці, що виникли внаслідок учинення кримінального, адміністративного правопорушення (п. 4 статті 18 Закону) [6];

3) доставлення у випадках i порядку, визначених законом, затриманих осіб, підозрюваних у вчиненні кримінального правопорушення, та осіб, які вчинили адміністративне правопорушення (п. 9 статті 18 Закону) [6];

4) здійснення супроводження транспортних засобів у випадках, визначених законом (п. 9 статті 18 Закону) [6];

5) застосування превентивних заходів (стаття 31 Закону) [6];

6) застосування заходів примусу (стаття 42 Закону) [6].

Відповідно до Кримінального процесуального кодексу України [5] фізична готовність $є$ налаштованістю до:

7) проведення слідчих (розшукових) дій, а саме:

7.1) проникнення до житла чи іншого володіння особи (ст. 233 КПК України) [5];

7.2) обшуку (ст. 234 КПК України) [5];

7.3) огляду (ст. 237 КПК України) [5], огляду трупа (ст. 238 КПК України) [5];

7.4) слідчого експерименту (ст. 240 КПК України) [5];

7.5) освідування особи (ст. 241 КПК України) [5];

8) проведення негласних слідчих (розшукових) дій [5]:

8.1) огляду і виїмки кореспонденції (ст. 262 КПК України) [5];

8.2) обстеження публічно недоступних місць, житла чи іншого володіння особи (ст. 267 КПК України) [5]; 
8.3) спостереження за особою, річчю або місцем (ст. 267 КПК України) та ін. [5];

Згідно із ЗУ «Про оперативно-розшукову діяльність» [8] фізична готовність $є$ налаштуванням до:

9) пошуку та фіксації фактичних даних про протиправні діяння окремих осіб та груп, відповідальність за які передбачена Кримінальним кодексом України... (ст. 1 3У) [8];

10) вжиття необхідних оперативно-розшукових заходів щодо попередження, своєчасного виявлення і припинення злочинів та викриття причин і умов, які сприяють вчиненню злочинів; здійснення профілактики правопорушень (п. 1 ст. 7) [8];

11) виконання письмових доручень слідчого, вказівок прокурора та ін. (п. 2 ст.7) [8];

12) взаємодії між собою та іншими правоохоронними органами, в тому числі відповідними органами іноземних держав та міжнародних антитерористичних організацій, із метою швидкого і повного попередження, виявлення та припинення злочинів (п. 5 ст.7) [8];

13) забезпечення із залученням інших підрозділів безпеки працівників суду i правоохоронних органів, осіб, які надають допомогу, сприяють оперативно-розшуковій діяльності, осіб, які беруть участь у кримінальному судочинстві, членів їхніх сімей та близьких родичів цих осіб (п. 6 ст.7) [8];

14) прийняття участі у здійсненні заходів щодо фізичного захисту ядерних установок, ядерних матеріалів, радіоактивних відходів, інших джерел іонізуючого випромінювання, а також у проведенні спеціальної перевірки щодо допуску до особливих робіт (п. 7 ст. 7) [8];

15) проведення контрольованої поставки та контрольованої i оперативної закупки товарів, предметів та речовин, у тому числі заборонених для обігу, у фізичних та юридичних осіб незалежно від форми власності з метою виявлення та документування фактів протиправних діянь (п. 2 ст. 8) [8];

16) проведення операцій із захоплення злочинців, припинення злочинів, розвідувально-підривної діяльності спецслужб іноземних держав, організацій та окремих осіб (п. 5 ст. 8) [8];

17) негласного виявлення та фіксації слідів тяжкого або особливо тяжкого злочину (п. 7 ст. 8) [8];

18) виконання спеціальних завдань із розкриття злочинної діяльності організованих груп чи злочинних організацій (п. 8 ст. 8) [8] тощо.

Отже, фізична готовність поліцейського $є$ різновидом психофізичної готовності, що полягає у специфічному налаштуванні особи на правомірне застосування в необхідних випадках фізичної сили.

що стосується вогневої готовності, то статтею 46 Закону [8] закріплено на законодавчому рівні застосування вогнепальної зброї. Вона визначає, що поліцейський уповноважений на зберігання, носіння вогнепальної зброї, а також на їі застосування і використання лише за умови, що він пройшов відповідну спеціальну підготовку [6]. Вона характеризується високою надійністю та постійною готовністю поліцейського кримінальної поліції до ведення стрільби.

Відповідно до ЗУ «Про національну поліцію» [6] вогнева готовність слідчого або оперативного працівника виявляється у налаштуванні особи до:

1) правомірного застосування та безпечного поводження зі зброєю;
2) застосування вогнепальної зброї для [6]:

2.1) для відбиття нападу на поліцейського або членів його сім'ї, у випадку загрози їхньому життю чи здоров'ю (п. 4.1 статті 46) [6];

2.2) захисту осіб від нападу, що загрожує їхньому життю чи здоров'ю (п. 4.2 статті 46) [6];

2.3) звільнення заручників або осіб, яких незаконно позбавлено волі (п. 4.3 статті 46) [6];

2.4) відбиття нападу на об'єкти, що перебувають під охороною, конвоєм, житлові та нежитлові приміщення, а також звільнення таких об'єктів у разі їх захоплення (п. 4.4 статті 46) [6];

2.5) затримання особи, яку застали під час вчинення тяжкого або особливо тяжкого злочину і яка намагається втекти (п. 4.5 статті 46) [6];

2.6) затримання особи, яка чинить збройний опір, намагається втекти з-під варти, а також озброєної особи, яка погрожує застосуванням зброї та інших предметів, що загрожують життю i здоров'ю людей та/або поліцейського (п. 4.6 статті 46) [6];

2.7) попередження про необхідність припинення протиправних дій (п. 5 статті 46) [6];

3) «... збройного нападу...» (п. 6.1 статті 46) [6];

4) «... збройного опору...» (п. 6.4 статті 46) [6];

5) «... спроби заволодіння вогнепальною зброєю...» (п. 6.5 статті 46) [6];

Відповідно до Положення про організацію службової підготовки працівників Національної поліції України [14] вогнева готовність $є$ налаштуванням до:

6) виконання прийомів швидкісної стрільби в різних умовах, із різних положень, із перенесенням вогню по мішенях [14]; [14].

7) відпрацювання нормативів із вогневої підготовки

Щодо «Інструкції із заходів безпеки при поводженні із вогнепальною зброєю», затвердженої наказом MBC України від 01.02.2016 № 70 [17], вогнева готовність $\epsilon$ налаштуванням до:

8) виконання службових завдань, пов'язаних із можливим застосуванням або використанням зброї (п.п. 1 п. 4 Розділу II Інструкції) [17];

9) проведення спеціальних операцій (п.п. 2 п. 4 Розділу II Інструкції) [17];

10) проведення практичних стрільб (п.п. 3 п. 4 Розділу II Інструкції) [17];

11) проведення командно-штабних навчань (п.п. 4 п. 4 Розділу II Інструкції) [17];

12) відрядження 3 вогнепальною зброєю (п.п. 5 п. 4 Розділу II Інструкції) [17].

Отже, на нашу думку, вогнева готовність, як різновид психофізичної готовності, - це налаштованість поліцейського до правомірного застосування зброї.

Що стосується тактико-спеціальної готовності, то слід зазначити, що вона полягає в налаштованості до виконання бойових та оперативно-службових завдань в екстремальних ситуаціях.

Відповідно до норм ЗУ «Про національну поліцію» [6] тактико-спеціальна готовність виявляється в налаштуванні до застосування фізичної сили, в тому числі спеціальних прийомів боротьби (рукопашного бою), для забезпечення особистої безпеки або/та безпеки інших осіб, припинення правопорушення, затримання особи, яка вчинила правопорушення, якщо застосування інших поліцейських заходів не забезпечує виконання полі- 
цейським повноважень, покладених на нього законом (п.1 ст. 44 ЗУ) [6].

Висновки 3 даного дослідження i перспективи подальших досліджень із цього напрямку. Таким чином, нами виокремлено такі різновиди психофізичної готовності, як: психологічна, фізична, тактико-спеціальна та вогнева, кожна з яких $є$ невід'ємною взаємодіючою складовою частиною. Визначено зміст кожного 3 різновидів психофізичної готовності на основі теоретичного аналізу нормативно нормативно-правових актів, які регламентують діяльність поліцейського кримінальної поліції. Проведене дослідження відкриває перспективи подальшого вивчення та дослідження питань психофізичної готовності поліцейського кримінальної поліції.

\section{Література}

1. Зеер Э.Ф., Симанюк Э.Э. Компетентносный подход к модернизации профессионального образования. Высшее образование в России. 2005. № 4. - С. 23-30.

2. Слободнюк Е.Г. Профессионально-ценностные ориентации как фактор становления личности будущего преподавателя : дисс. ... к. пед. Н. Магнитогорск, 2000. 194 c.

3. Конституція України : Закон України від 28.06.1996 № 254к/96-ВР / Верховна Рада України. URL : http://zakon2.rada.gov.ua/aws/show/254к/96-вp.

4. Кримінальний кодекс України : Закон України від 05.04.2001 № 2341-ІІ // Верховна Рада України. URL : http://zakon2.rada.gov.ua/laws/show/2341-14.

5. Кримінальний процесуальний кодекс України : Кодекс України, Закон, Кодекс від 13.04.2012 № 4651-VI. Відомості Верховної Ради України (ВВР). 2013. № 9-10, № 11-12, № 13. Ст. 88.

6. Закон України «Про національну поліцію від 2015 року, № 40-41 // Верховна Рада України. URL : http://zakon3.rada.gov.ua/laws/show/580-19.

7. Про державну службу : Закон України від 10.12.2015 р. № 889- VIII. Відомості Верховної Ради. 2016. № 4. СТ. 43.

\section{Актуальні проблеми історико-правової та міжнародно-правової науки}

8. Про оперативно-розшукову діяльність : Закон України. URL : https://zakon1.rada.gov.ua/cgi-bin/laws/ main. cgi?nreg=2135-12.

9. Про організаційно-правові основи боротьби з організованою злочинністю : Закон України від 30 червня 1993 р. Відомості Верховної Ради України. 1993. № 35.

10. Про Дисциплінарний статут органів внутрішніх справ України : Закон України від 22 лютого 2006 р. Відомості Верховної Ради України. 2006. № 29.

11. Положення про Національну поліцію. URL : https://zakon3.rada.gov.ua/laws/show/877-2015-\%D0\%BF.

12. Про затвердження Інструкції про порядок проведення атестування поліцейських : Наказ МВС України від 17.11.2015 № 1465. URL : http:/ /zakon.rada.gov.ua.

13. Про затвердження Інструкції з організації реагування на заяви та повідомлення про кримінальні, адміністративні правопорушення або події та оперативного інформування в органах (підрозділах) Національної поліції України : Наказ МВС України від 16.02.2018 № 111. URL : http://zakon.rada.gov.ua.

14. Положення про організацію службової підготовки працівників Національної поліції України. URL : https://zakon.rada.gov.ua/laws/show/z0260-16.

15. Про затвердження Порядку організації системи психологічного забезпечення поліцейських, працівників Національної поліції України та курсантів (слухачів) закладів вищої освіти із специфічними умовами навчання, які здійснюють підготовку поліцейських. URL : https://zakon.rada.gov.ua/laws/show/z0348-19\#n15.

16. Наказ Міністерства внутрішніх справ України «Про затвердження Положення з організації перевірки рівня фізичної підготовленості кандидатів до вступу на службу в Національну поліцію України» від 9 лютого 2016 р. № 90.

17. Інструкція із заходів безпеки при поводженні зі зброєю : Наказ Міністерства внутрішніх справ України 01.02.2016 № 70. URL : https://zakon.rada.gov.ua/laws/ show/z0250-16.

Дьорова О. М., ад'юнкт кафедри криміналістики та психології Одеського державного університету внутрішніх справ 